\title{
METODE INTERNALISASI NILAI-NILAI MORAL AGAMA ISLAM DALAM PROSES PEMBELAJARAN DI UNIVERSITAS KH.A.WAHAB HASBULLAH TAMBAKBERAS JOMBANG
}

\author{
Drs. Waslah, M.Pd.I
}

NIDN : 2123036801

\begin{abstract}
This study aims to describe the strategy of Internalization of Islamic moral values in the learning process at the University of KH. A. Wahab Hasbullah Tambakberas Jombang. Through the description of the strategy, it is expected to find the right method to internalize Islamic moral values in the learning process at Universitas KH.A. Wahab Hasbullah Tambakberas Jombang. This research is descriptive research using qualitative approach. Research subjects are lecturers who teach in Information Management Studies Program, Economics Study Program Faculty of Engineering Information and Management, at the University of KH. A. Wahab Hasbullah Tambakberas Jombang. Data were collected through interviews, observation, and documentation. Technique examination of data validity used is triangulation technique. The results showed that the strategy of internalization of Islamic moral values in learning include: modeling, analysis of actual problems that are developing in society, the planting of contextual educational values, and the strengthening of Islamic moral values that have been previously owned by students.
\end{abstract}

\section{A. Pendahuluan}

Pendidikan merupakan pilihan strategis bagi suatu bangsa untuk bangkit dari keterpurukan. Begitu pun bagi Indonesia, sudah menjadi keharusan untuk menempatkan pendidikan sebagai prioritas utama dalam pembangunan. Secara tegas upaya untuk menciptakan sumber daya manusia yang berkualitas tersebut tertuang dalam lembaran yuridis negara berupa 


\section{Drs. Waslah, M.Pd.I}

Undang-undang tentang sistem pendidikan nasional. Melalui Undang-undang Nomor 20 Tahun 2003 tentang Sistem Pendidikan Nasional, pemerintah mengusahakan dan menyelenggarakan satu sistem pendidikan nasional yang dapat meningkatkan keimanan dan ketakwaan kepada Tuhan Yang Maha Esa serta akhlak mulia dalam mencerdaskan kehidupan bangsa.

Pendidikan sudah sejak zaman dahulu bertujuan untuk membentuk manusia yang utuh dan lengkap meliputi berbagai aspek. Pendidikan tidak hanya berorientasi pada aspek akademis semata dalam rangka penguasaan ilmu dan teknologi. Kemajuan teknologi dan ekonomi tidak menjamin hadirnya rasa bahagia di hati manusianya, malah dapat membawa dampak pada hilangnya jati diri dan makna kehidupan. Pendidikan yang dikembangkan seharusnya seimbang antara kecerdasan intelektual, emosional, dan spiritual. Menghadirkan spiritualitas dalam pendidikan akan memberi makna besar terhadap kehidupan bangsa. Keyakinan terhadap keberadaan Tuhan akan menimbulkan komitmen kuat untuk selalu memberikan yang terbaik untuk bangsa. ${ }^{1}$ Internalisasi nilai-nilai moral religius dalam proses pembelajaran merupakan bagian penting yang perlu dikembangkan agar ilmu yang diperoleh peserta didik lebih bermakna.

Nilai dan moral merupakan dua konsep berbeda yang dalam penggunaannya seringkali disandingkan. Bertens menjelaskan pengertian nilai

${ }^{1}$ Agustian, Ary G Peran ESQ Daalam Peningkatan Kualitas Pendidikan (Yogyakarta : UNY Press 2008), 12 


\section{Metode Internalisasi Nilai-Nilai Moral Agama Islam Dalam Proses Pembelajaran Di Universitas KH.A.Wahab Hasbullah Tambakberas Jombang}

melalui cara memperbandingkannya dengan fakta. ${ }^{2}$ Fakta menurutnya adalah sesuatu yang ada atau berlangsung begitu saja. Sementara nilai adalah sesuatu yang berlaku, sesuatu yang memikat atau menghimbau kita. Fakta dapat ditemui dalam konteks deskripsi semua unsurnya dapat dilukiskan satu demi satu dan uraian itu pada prinsipnya dapat diterima oleh semua orang. Nilai berperanan dalam suasana apresiasi atau penilaian dan akibatnya sering akan dinilai secara berbeda oleh orang banyak. Nilai selalu berkaitan dengan penilaian seseorang, sementara fakta menyangkut ciri-ciri obyektif saja. Definisi lain tentang nilai dikemukakan oleh Richard Merril menurutnya nilai adalah patokan atau standar pola-pola pilihan yang dapat membimbing seseorang atau kelompok ke arah satisfaction, fulfillment, and meaning. ${ }^{3}$ Menurut Sandin (Koyan, 2000: 13-14), patokan atau kriteria tersebut memberi dasar pertimbangan kritis tentang pengertian religius, estetika, dan kewajiban moral. ${ }^{4}$

Sementara istilah moral menurut Prent berasal dari bahasa Latin mores dari suku kata mos, yang artinya adat istiadat, kelakuan, tabiat, watak, akhlak. ${ }^{5}$ Ouska dan Whellan (Ruminiati, 2007: 32) mengartikan moral sebagai prinsip baik-buruk yang ada dan melekat dalam diri seseorang. ${ }^{6}$ Namun demikian, walaupun moral itu berada di dalam diri individu tetapi moral berada dalam

\footnotetext{
2 Bertens, K Etika ( Jakarta : Gramedia Pustaka Utama 2007 ) 140

${ }^{3}$ Koyan I Wayan, Pendidikan Moral Lintas Budaya (Jakarta: Dirjen Dikti DEpdiknas, 2000 ) 13

${ }^{4}$ Ibid 14

${ }^{5}$ Cholisin, Dasar Dan Konsep Pendidikan Pancasila ( Yogyakarta : Laboratorium Jurusan PMP dan KN,1989) 25.

${ }^{6}$ Ruminiati, Modul Pendidikan Kewarganegaraan SD Program SI PJJ.( Jakarta : Dirjen Dikti Depdiknas RI. $2007) 32$.
} 


\section{Drs. Waslah, M.Pd.I}

suatu sistem yang berwujud aturan. Moral dan moralitas merupakan dua konsep yang berbeda. Moral adalah prinsip baik-buruk sedangkan moralitas merupakan kualitas pertimbangan baik-buruk. Dengan demikian, hakekat dan makna moralitas dapat dilihat dari cara individu yang memiliki moral dalam mematuhi maupun menjalankan aturan.

Dalam menginternalisasikan nilai-nilai moral; Simon, Howe, dan Kirschenbaum (Wahab, 2007: 1.23) menawarkan 4 (empat) pendekatan yang dapat digunakan, yaitu pendekatan penanaman moral, pendekatan transmisi nilai bebas, pendekatan teladan, dan pendekatan klarifikasi nilai. Menurut Kirschenbaum (1995: 16-17) pendidikan nilai perlu dilakukan dengan menggunakan pendekatan secara komprehensif. Pendekatan secara komprehensif dalam pendidikan nilai maksudnya adalah pendidikan nilai yang menyeluruh atau komprehensif yang dapat ditinjau dari segi metode yang digunakan, pendidik yang berpartisipasi (guru, orang tua), dan konteks berlangsungnya pendidikan nilai (sekolah, keluarga).

Menurut Zuchdi (2008: 48) dalam menerapkan metode keteladanan guru dan orang tua perlu memiliki keterampilan asertif dan keterampilan menyimak. Kedua keterampilan ini sangat diperlukan untuk menjalin hubungan antarpribadi dan antarkelompok. Oleh karena itu, guru dan orang tua harus dapat dijadikan 


\section{Metode Internalisasi Nilai-Nilai Moral Agama Islam Dalam Proses Pembelajaran}

Di Universitas KH.A.Wahab Hasbullah Tambakberas Jombang

contoh bagi anak-anak. Keterampilan asertif adalah keterampilan mengemukakan pendapat secara terbuka dengan cara-cara yang tidak melukai perasaan orang lain. Keterampilan menyimak ialah keterampilan mendengarkan dengan penuh pemahaman dan secara kritis. Kedua keterampilan ini harus dikembangkan secara seimbang karena merupakan komponen vital dalam berkomunikasi. Anak yang memiliki kedua keterampilan ini akan menjadi anak yang dapat menghargai pendapat orang lain dan secara asertif dapat menyampaikan gagasannya kepada orang lain.

Selain komprehensif dari segi metode, pendidikan nilai juga harus komprehensif dari segi isi, waktu, pelaku, dan penilaian. Dari segi isi, pendidikan nilai harus meliputi semua permasalahan yang berkaitan dengan pilihan nilai-nilai yang bersifat peribadi sampai pertanyaan-pertanyaan etika secara umum. Komprehensif dalam hal waktu ialah pendidikan nilai berlangsung di setiap saat sepanjang hidup anak. Komprehensif dari segi pelaku, bahwa pendidikan nilai dapat dilakukan oleh semua orang dewasa, sadar atau tidak, direncanakan atau tidak direncanakan. Kemudian komprehensif dalam penilaian, maksudnya adalah dalam mengukur efektivitas dan kemajuan pendidikan nilai menggunakan evaluasi formatif dan sumatif yang mengukur pengetahuan, sikap, dan keterampilan nilai.

Uraian di atas, menunjukkan bahwa ada banyak metode yang dapat digunakan dalam menginternalisasikan nilai. Pendidikan nilai dapat dilakukan 


\section{Drs. Waslah, M.Pd.I}

di setiap jenjang pendidikan, termasuk di perguruan tinggi. Untuk menciptakan suasana kampus yang nyaman, tenteram dan penuh religiusitas tentu menjadi tanggungjawab setiap civitas di sebuah perguruan tinggi. Memulai semua itu tentu perlu kajian mendalam darimana dan bagaimana metode yang tepat untuk digunakan dalam mengimplementasikan nilai-nilai moral religius dalam kehidupan kampus. Mengingat begitu banyaknya nilainilai moral religius yang ada, maka kajian penelitian ini dibatasi pada nilainilai moral religius berupa nilai ketaqwaan, kejujuran, keihkhlasan, dan tanggungjawab. Kajian mendalam melalui penelitian tentang internalisasi nilai-nilai moral religius dalam kehidupan kampus merupakan langkah strategis yang harus segera dilakukan. Harapannya melalui sebuah penelitian akan ditemukan suatu model atau strategi yang tepat dan sesuai dalam menginternalisasikan nilai-nilai moral religius dalam proses pembelajaran di perguruan tinggi.

\section{B. Metode Penelitian}

Penelitian ini merupakan penelitian deskriptif dengan menggunakan pendekatan kualitatif. Merupakan penelitian deskriptif karena penelitian ini bermaksud untuk membuat gambaran mengenai situasi atau kejadian, yaitu strategi internalisasi nilai-nilai moral religius dalam proses pembelajaran di perguruan tinggi. Hal ini sejalan dengan pendapat Nazir (2005), bahwa 


\section{Metode Internalisasi Nilai-Nilai Moral Agama Islam Dalam Proses Pembelajaran} Di Universitas KH.A.Wahab Hasbullah Tambakberas Jombang

penelitian deskriptif bertujuan untuk membuat gambaran mengenai situasi atau kejadian sehingga berkehendak mengadakan akumulasi data dasar belaka. ${ }^{7}$ Penelitian ini dilakukan di Jurusan Pendidikan Kewarganegaraan dan Hukum, Fakultas Ilmu Sosial dan Ekonomi, Universitas Negeri Yogyakarta. Subyek penelitian ini adalah lima orang dosen yang mengajar di Jurusan Pendidikan Kewarganegaraan dan Hukum. Subyek tersebut dipilih berdasarkan pertimbangan rumpun keilmuan yang ada di Jurusan Pendidikan Kewarganegaraan dan Hukum meliputi: rumpun hukum, moral, dan politik.

Teknik pengumpulan data yang digunakan dalam penelitian ini adalah wawancara, observasi, dan dokumentasi. Wawancara digunakan untuk menjaring data atau informasi yang berkaitan dengan strategi yang digunakan dalam internalisasi nilai-nilai moral religius. Obeservasi digunakan untuk memperoleh data mengenai pelaksanaan metode yang digunakan dalam menginternalisasikan nilai-nilai moral religius dalam proses pembelajaran. Dokumentasi digunakan untuk memperoleh data mengenai gambaran keberadaan obyek yang diteliti. Selain itu, untuk melengkapi data hasil wawancara dan observasi. Untuk mendapatkan data yang dapat dipertanggungjawabkan secara ilmiah, maka dari data-data yang telah terkumpul terlebih dahulu dilakukan pemeriksaan keabsahannya. Dalam penelitian ini teknik pemeriksaan keabsahan data yang digunakan adalah

\footnotetext{
${ }^{7}$ Nazir, Moh, Metode Penelitian ( Bogor: Ghalia Indonesia,2005 ) 55
} 


\section{Drs. Waslah, M.Pd.I}

teknik triangulasi, yaitu teknik penyilangan informasi yang diperoleh dari sumber sehingga pada akhirnya hanya data yang absah saja yang

digunakan untuk mencapai hasil penelitian. ${ }^{8}$ Teknik triangulasi yang digunakan dalam penelitian ini adalah triangulasi metode dan sumber, yaitu dengan cara mengkonfirmasi ulang informasi hasil wawancara dengan dokumentasi dan observasi. Data penelitian yang diperoleh dari sumber yang berbeda melalui wawancara dikonfirmasi ulang dengan data yang diperoleh melalui observasi dan dokumentasi. Data yang digunakan dalam penelitian ini adalah data yang absah setelah melalui proses penyilangan informasi. Teknik analisis data yang digunakan dalam penelitian ini adalah teknik analisis induktif, yaitu analisis yang bertolak dari data dan bermuara pada simpulan-simpulan umum.

\section{Hasil Penelitian}

Dalam menginternalisasikan nilai-nilai moral religius, setiap dosen memiliki cara atau strategi yang berbeda-beda. Perbedaan tersebut disebabkan karena belum jelasnya nilai-nilai moral religius yang hendak ditanamkan dalam proses pembelajaran. Artinya belum ada common values (nilai-nilai umum yang disepakati bersama) untuk diimplementasikan dalam proses pembelajaran di kelas. Nilai-nilai moral religius yang masih terlalu umum

\footnotetext{
${ }^{8}$ Arikunto, Suharsimi, Prosedur Penelitian Suatu Pendekatan Praktek, ( Jakarta: Rineka Cipta, 2006 ) 18
} 


\section{Metode Internalisasi Nilai-Nilai Moral Agama Islam Dalam Proses Pembelajaran}

Di Universitas KH.A.Wahab Hasbullah Tambakberas Jombang

perlu dijabarkan lebih rinci lagi menjadi indikator-indikator, untuk memperjelas nilai apa saja yang hendak ditanamkan dalam proses pembelajaran. Masih terlalu umumnya nilai-nilai moral religius yang hendak diimplementasikan menyebabkan terdapat penafsiran yang berbeda dari masing-masing dosen terhadap nilai-nilai moral yang hendak diimplementasikan dalam proses pembelajaran.

Perbedaan sudut pandang terhadap nilai-nilai moral religius berimplikasi terhadap beraneka ragamnya strategi yang diterapkan oleh dosen dalam mengimplementasikan nilai-nilai moral tersebut dalam proses pembelajaran. Secara umum ada beberapa strategi yang diterapkan oleh para dosen di Fakultas Tehnik Informasi dan Manajemen dalam mengimplementasikan nilai-nilai moral religius dalam proses pembelajaran. Masing-masing strategi yang diterapkan tersebut memiliki ciri dan keunggulan tersendiri. Uraian lengkap dari masing-masing strategi yang diterapkan itu adalah sebagai berikut:

\section{Strategi Keteladanan (modelling)}

Berdasarkan hasil wawancara yang peneliti lakukan, ada beberapa dosen yang menerapkan strategi implementasi nilai-nilai moral religius melalui metode keteladanan. Strategi keteladanan ini dapat dibedakan menjadi keteladanan internal (internal modelling) dan keteladanan eksternal (external modelling). Keteladanan internal dapat dilakukan melalui 


\section{Drs. Waslah, M.Pd.I}

pemberian contoh yang dilakukan oleh dosen sendiri dalam proses pembelajaran. Sementara keteladanan eksternal dilakukan dengan pemberian contoh-contoh yang baik dari para tokoh yang dapat diteladani, baik tokoh lokal maupun tokoh internasional.

Nilai moral religius berupa ketaqwaan, kejujuran, keikhlasan, dan tanggungjawab dapat ditanamkan kepada mahasiswa melalui keteladanan, baik keteladanan internal maupun eksternal. Keteladanan internal yang dilakukan oleh dosen, misalnya dilakukan dengan cara mengawali dan mengakhiri setiap perkuliahan dengan berdoa. Dosen senantiasa memberi contoh untuk disiplin dalam beberapa hal seperti kebersihan ruang kelas, datang tepat waktu, dan memiliki komitmen terhadap kontrak belajar yang telah disepakati bersama. Untuk dapat menjadi teladan yang baik diperlukan suatu proses yang panjang. Seorang dosen melalui kebiasaankebiasaan baik yang selalu dia lakukan didalam kelas dapat diteladani oleh mahasiswa.

Hal lain yang dapat dilakukan dosen terkait dengan keteladanan internal adalah melalui pemberian atau cerita tentang "pengalaman religius" yang dialami oleh dosen. Terkadang ada seorang dosen yang memiliki pengalaman religius menarik dalam hidupnya, dan hal itu menjadi sesuatu menarik yang dapat diteladani oleh mahasiswa. Sebagai contoh mengenai kekuatan sebuah doa yang mengalahkan segala-galanya. Kedekatan kepada 


\section{Metode Internalisasi Nilai-Nilai Moral Agama Islam Dalam Proses Pembelajaran}

Di Universitas KH.A.Wahab Hasbullah Tambakberas Jombang

Allah sebagai Tuhan yang Maha Pengasih dan Penyayang telah mengantarkan kepada suatu kesuksesan yang mungkin tidak disangka sebelumnya. Pengalaman semacam ini menunjukkan pentingnya pemahaman tentang keberadaan sesuatu Yang Maha Kuasa di atas segalagalnya. Artinya, pemahaman tentang nilai-nilai religius terutama terkait dengan nilai ketaqwaan dalam kehidupan seorang manusia menjadi suatu hal yang penting.

Keteladanan yang kedua adalah keteladanan eksternal, yaitu keteladanan yang datang dari luar diri dosen. Keteladanan semacam ini dapat dilakukan misalnya dengan menyajikan cerita tentang tokoh-tokoh agama yang dapat dijadikan sebagai teladan dalam meniti kehidupan. Misalnya, tokoh nabi Muhammad, para sahabat nabi Muhammad, Jenderal Besar Soedirman, dan tokoh-tokoh penting lain baik di Indonesia maupun di luar Indonesia yang patut untuk diteladani. Penyajian cerita yang menarik tentang kisah para tokoh tersebut diharapkan menjadikan mahasiswa mengidolakan dan meniru tindakan positif yang mereka lakukan. Para tokoh tersebut memiliki sikap ketaqwaan, kejujuran, keikhlasan, dan tanggungjawab yang dapat diteladani oleh para mahasiswa. Nabi Muhammad merupakan contoh atau teladan sosok manusia yang memiliki ketaqwaan luar biasa yang patut untuk diteladani. 


\section{Drs. Waslah, M.Pd.I}

Selain melalui kisah para tokoh teladan, strategi keteladanan eksternal dapat dilakukan dengan memutarkan film-film tokoh. Misalnya keteladanan tentang kegigihan seorang penulis melalui film freedom writers. Atau kisah- kisah terbaru seperti film "Laskar Pelangi". Dari kisah-kisah yang disajikan melalui film tersebut mahasiswa dapat memetik suatu hikmah yang bermanfaat untuk dirinya. Kejujuran, keikhlasan, tanggungjawab, kepolosan, kegigihan, kerja keras, dan masih banyak lagi nilai-nilai moral yang dapat diteladani melalui cerita film yang ditayangkan di dalam kelas. Mahasiswa dapat menganalisis dan mendiskusikan cerita film yang ditayangkan di dalam kelas, sehingga suasana pembelajaranpun akan menjadi lebih menarik.

Melalui strategi keteladanan ini, memang dosen tidak secara langsung memasukan hal-hal terkait dengan keteladanan itu dalam rencana pembelajaran. Artinya, nilai-nilai moral religius seperti ketaqwaan, kejujuran, keikhlasan, dan tanggungjawab yang ditanamkan kepada para mahasiswa merupakan sesuatu yang sifatnya hidden curriculum. Melalui cerita para tokoh penting dan pemutaran film seorang dosen berharap nilainilai yang terkandung di dalamnya dapat menjadi sesuatu yang menarik dan dapat ditiru atau diteladani oleh para mahasiswa.

\section{Analisis Masalah atau Kasus}




\section{Metode Internalisasi Nilai-Nilai Moral Agama Islam Dalam Proses Pembelajaran Di Universitas KH.A.Wahab Hasbullah Tambakberas Jombang}

Ada dosen Prodi Teknik Informasi dan Manajemen yang menerapkan strategi ini dalam mengimplementasikan nilai-nilai moral religius dalam proses pembelajaran. Mahasiswa diberikan tugas untuk menganalisis kasus yang memuat nilai-nilai moral religius. Kasus-kasus tersebut mereka dapatkan melalui penelusuran artikel di berbagai media. Nilai moral religius yang hendak ditanamkan melalui strategi ini adalah nilai moral ketaqwaan, kejujuran, keikhlasan, dan tanggungjawab. Setelah mereka menemukan sejumlah kasus yang mengandung nilai-nilai moral religius tersebut, langkah selanjutnya adalah melakukan analisis kasus.

Strategi ini sebenarnya dapat dikatakan sebagai bentuk dari klarifikasi nilai (value clarification). Karena dalam pelaksanaannya mahasiswa diminta untuk melakukan klarifikasi terhadap nilai-nilai yang terkandung dalam suatu masalah yang mereka temukan. Dari analisis kasus itulah mahasiswa akan mendapatkan nilai positif dan negatif dari sebuah kasus. Dengan kata lain strategi ini hampir sama dengan problem based learning. Mahasiswa diminta untuk menganalisis permasalahan, lalu mereka memberikan solusi terbaik terhadap permasalahan yang mereka diskusikan. Setelah permasalahan selesai mahasiswa dapat mengambil hikmah atau dapat belajar dari masalah yang dia pecahkan tersebut.

Strategi analisis masalah atau kasus ini sebenarnya menjadi sesuatu yang menarik dan penting untuk dilakukan. Permasalahan-permasalahan tentang 


\section{Drs. Waslah, M.Pd.I}

implementasi nilai-nilai religius seperti ketaqwaan, kejujuran, keikhlasan, dan tanggungjawab dalam kehidupan sehari-hari sering ditemukan dalam tulisan-tulisan atau artikel di media massa. Apalagi artikel-artikel yang dimuat di media massa ini biasanya merupakan artikel yang sedang aktual untuk dibicarakan. Misalnya, terkait dengan nilai moral kejujuran dan tanggungjawab. Seringkali media massa memuat artikel tentang kasus korupsi dan penyalahgunaan kekuasaan oleh pejabat pemerintah. Artikelartikel yang memuat berbagai kasus tersebut dapat dijadikan sebagai sarana bagi mahasiswa untuk menganalisis muatan nilai moral yang terkandung di dalamnya. Melalui pembahasan yang menarik di kelas mahasiswa biasanya akan merasa senang dan serius dalam mengikuti perkuliahan.

Hal terpenting lain yang perlu diperhatikan dalam menerapkan strategi analisis kasus ini adalah bagaimana mahasiswa dapat menerapkan nilai-nilai moral religius tersebut dalam kehidupan nyata. Mahasiswa tidak saja mampu melakukan analisis kasus dan dapat memecahkannya, melainkan dapat secara nyata meningternalisasikan nilai-nilai moral religius tersebut dalam kehidupannya. Jadi setelah membahas atau menganalisis kasus yang ada dalam artikel, mahasiswa dapat menemukan nilai-nilai religius seperti ketaqwaan, kejujuran, keikhlasan, dan tanggungjawab. Nilainilai tersebut harapannya dapat diimplementasikan dalam kehidupan 
sehari-hari. Sehingga secara perlahan tapi pasti kepribadian atau moral mahasiswa akan terbentuk menjadi kepribadian yang baik.

\section{Penanaman Nilai Edukatif yang Kontekstual}

Strategi ini dapat dilakukan dengan secara langsung atau tidak langsung memasukan nilai-nilai moral religius dalam materi pembelajaran. Konsep-konsep yang dikembangkan dalam suatu mata kuliah harus mengandung nilai-nilai edukatif. Artinya, konsep yang dikembangkan dalam suatu mata kuliah jangan hanya mengedepankan kajian teoritis tentang pengembangan ilmu tersebut. Akan tetapi bagaimana konsepkonsep yang dikembangkan juga mengandung unsur-unsur edukatif penting yang patut untuk dipelajari.

Dalam memberikan konsep-konsep yang memiliki nilai edukatif ini sebaiknya dimulai dari hal-hal yang sifanya kontekstual dan aktual. Misalnya saja terkait dengan pengesahan rancangan undang-undang anti pornografi dan pornoaksi. Pro dan kontra rancangan undang-undang ini menjadi sesuatu yang menarik untuk diberikan di kelas. Dosen dalam memberikan contoh-contoh yang kontekstual dan aktual ini dapat dilakukan ketika melakukan kegiatan apersepsi atau pendahuluan pembelajaran.

Untuk dapat secara jelas menanamkan nilai-nilai edukatif yang kontesktual, maka perlu dimasukan ke dalam proses pembuatan 


\section{Drs. Waslah, M.Pd.I}

perancangan pembelajaran di kelas. Dosen dapat membuat dan menuliskan nilai-nilai edukatif yang mengandung unsur religius yang meliputi nilai ketawqaan, kejujuran, keikhlasan, dan tanggungjawab dalam rencana pelaksanaan pembelajaran. Artinya, nilai-nilai moral religius tersebut dituliskan secara jelas kapan akan disampaikan dan memerlukan waktu berapa lama dalam penyampaian nilai-nilai moral religius tersebut di kelas.

Permasalahannya terletak pada belum adanya nilai-nilai moral religius kontekstual permanen yang telah disepakati bersama. Nilai-nilai moral religius yang aktual dan kontekstual seringkali berjalan seiring dengan permasalahan yang sedang muncul di masyarakat. Misalnya, ketika sedang membicarakan kasus korupsi akan menjadi tema yang aktual dan kontekstual untuk menanamkan nilai moral berupa kejujuran dan tanggungjawab. Akan tetapi ketika kasus korupsi sudah tidak aktual lagi, maka nilai moral religius yang kontekstual akan berganti. Oleh karena itu perlu dilakukan suatu lokakarya untuk menentukan nilai-nilai moral religius yang kontekstual. Melalui kegiatan seperti lokakarya diharapkan akan disepakati nilai-nilai apa saja yang sifatnya kontekstual dan dapat diterapkan dalam proses pembelajaran di kelas.

\section{Penguatan Nilai-nilai yang Ada}


Strategi ini dilakukan dengan sebuah asumsi bahwa mahasiswa sebenarnya telah memiliki nilai-nilai moral religius seprti ketaqwaan, kejujuran, keikhlasan, dan tanggungjawab. Namun bagaimana keyakinan dan pengamalan mereka terhadap nilai-nilai tersebut perlu untuk dikuatkan. Keyakinan terhadap nilai-nilai moral religius yang telah dimiliki oleh mahasiwa terkadang mengalami pasang surut. Mahasiswa terkadang karena pengaruh lingkungan atau teman sebaya melupakan akan pentingnya nilai- nilai moral religius tersebut dalam kehidupan sehari-hari. Setiap dosen sebenarnya memiliki kesempatan yang sama untuk dapat melakukan hal itu. Dosen dapat menyisipkan ruh nilai-nilai moral religius dalam setiap perkuliahan. Penguatan dapat dilakukan dosen setiap saat memberikan kuliah. Artinya, tidak perlu secara langsung menuliskannya dalam sebuah rencana pelaksanaan pembelajaran di kelas. Penyisipan nilai- nilai moral religius ini juga dapat dilakukan untuk setiap mata kuliah. Setiap dosen pengampu mata kuliah dapat melakukan penguatan nilai-nilai moral religius. Hanya saja bagaimana bentuk penguatan nilainilai moral yang dilakukan masing-masing dosen memiliki kekhasan. Penguatan nilai-nilai moral religius seperti ketaqwaan, kejujuran, keikhlasan, dan tanggungjawab bukan semata-mata menjadi tanggung jawab dosen yang mengampu mata kuliah Pendidikan Agama. 


\section{Drs. Waslah, M.Pd.I}

Keberanian untuk setiap saat menyisipkan ruh nilai-nilai moral religius dalam perkuliahan menjadi tantangan besar para dosen. Semua itu dilakukan melalui suatu proses yang panjang. Tidak serta merta nilainilai moral religius ini akan menjadi nilai-nilai yang langsung terinternalisasi dalam diri mahasiswa. Proses panjang itu tetap harus dilakukan agar para mahasiswa memiliki pemahaman yang kuat terhadap nilai-nilai moral religius yang harus mereka implementasikan dalam kehidupan sehari-hari. Selain itu, perlu ada komitmen dan kerjasama antar dosen pengampu mata kuliah untuk menciptakan sistem atau suasana pembelajaran yang memungkinkan nilai- nilai moral religius tersebut dapat ditanamkan dengan baik.

\section{Pembahasan}

Strategi internaliasi nilai-nilai moral religius dalam proses pembelajaran yang diterapkan oleh masing-masing dosen memiliki keragaman. Strategi tersebut dipilih berdasarkan nilai moral religius apa yang akan ditanamkan kepada mahasiswa. Setiap nilai moral memiliki karakteristik tersendiri sehingga tidak dapat menggunakan metode yang sama untuk semua nilai moral religius yang akan ditanamkan kepada mahasiswa. Keberhasilan metode internalisasi nilai-nilai moral religius yang digunakan juga sangat tergantung kepada kemampuan dan pengalaman seorang dosen dalam memilih dan 


\section{Metode Internalisasi Nilai-Nilai Moral Agama Islam Dalam Proses Pembelajaran Di Universitas KH.A.Wahab Hasbullah Tambakberas Jombang}

menerapkan metode yang tepat untuk menginternalisasikan nilai-nilai moral yang akan ditanamkan.

Sebelum menerapkan metode internalisasi nilai-nilai moral religius dalam proses pembelajaran, seharusnya ada kesepakatan bersama mengenai nilai moral religius apa yang akan diinternalisasikan dalam proses pembelajaran. Kemudian setelah disepakati, nilai-nilai tersebut perlu dijabarkan ke dalam indikator- indikator yang lebih terperinci. Adanya pemahaman yang sama terhadap nilai moral religius yang akan ditanamkan kepada mahasiswa sebenarnya dapat memudahkan para dosen ketika akan memilih strategi yang tepat untuk menginternalisasikan nilai-nilai moral religius dalam proses pembelajaran. Perbedaan pemahaman atau persepsi mengenai nilai-nilai moral religius yang akan ditanamkan menyebabkan beragam pula metode yang pilih oleh para dosen.

Strategi internalisasi nilai-nilai moral religius dalam proses pembelajaran dapat diterapkan oleh dosen secara terencana ataupun tidak terencana. Secara terencana dilakukan melalui memasukan indikator-indikator nilai moral religius yang akan ditanamkan ke dalam rencana pelaksanaan pembelajaran. Dosen membuat skenario pembelajaran yang sengaja dirancang untuk menanamkan nilai-nilai moral tertentu dalam pembelajaran. Dosen dapat pula menyisipkan nilai-nilai moral religius ketika menyampaikan materi perkuliahan. Sedangkan secara tidak terencana, dosen dapat memasukkan 


\section{Drs. Waslah, M.Pd.I}

nilai-nilai moral pada saat-saat tertentu yang memungkinkan seorang dosen dapat menyisipkan nilai-nilai moral religius. Penyisipan nilai-nilai moral religus ini dapat dilakukan di bagian pendahuluan, inti, ataupun penutup perkuliahan.

Berdasarkan uraian hasil penelitian yang telah dikemukakan, menunjukkan bahwa pendekatan yang digunakan oleh para dosen dalam menginternalisasikan nilai-nilai moral religius berbeda-beda. Hal ini sejalan dengan pendapat Simon, Howe, dan Kirschenbaum (Wahab, 2007: 1.23) yang menyatakan bahwa dalam menginternalisasikan nilai-nilai moral dapat menggunakan empat pendekatan yang meliputi pendekatan penanaman moral, pendekatan transmisi nilai bebas, pendekatan teladan, pendekatan klarifikasi nilai. Hasil penelitian ini menggambarkan bahwa pendekatan yang digunakan dalam menginternalisasikan nilai-nilai moral religius yang diterapkan oleh para dosen di Jurusan Pendidikan Kewarganegaraan dan Hukum meliputi: pendekatan penanaman moral, pendekatan teladan, dan pendekatan klarifikasi nilai.

Pendekatan penanaman moral digunakan untuk menanamkan nilai-nilai moral yang dianggap sudah seharusnya diterima karena keberadaannya tidak perlu diragukan lagi. Nilai-nilai moral religius seperti aqidah keagamaan dan ketaqwaan merupakan nilai moral yang keberadaannya tidak diragukan lagi. Pendekatan ini digunakan oleh dosen melalui penerapan strategi penguatan 


\section{Metode Internalisasi Nilai-Nilai Moral Agama Islam Dalam Proses Pembelajaran Di Universitas KH.A.Wahab Hasbullah Tambakberas Jombang}

nilai-nilai moral religius yang telah dimiliki oleh mahasiswa. Penguatan terhadap nilai moral religius ketaqwaan yang dimiliki oleh mahasiswa salah satunya dapat dilakukan dalam pembelajaran Pendidikan Agama. Melalui materi pembelajaran Pendidikan Agama, dosen dapat melakukan penguatanpenguatan terhadap nilai ketaqwaan yang dimiliki oleh mahasiswa.

Pendekatan teladan digunakan untuk mengajarkan nilai-nilai moral melalui penunjukkan figur publik yang kepribadiannya patut diteladani. Figur publik ini misalnya para nabi atau rasul, dosen atau guru, orang tua, tokoh masyarakat, ilmuwan, dan ulama. Pendekatan ini digunakan oleh dosen melalui penerapan strategi keteladanan (modeling). Keteladanan yang digunakan dalam penanaman nilai-nilai moral religius ini berupa keteladan internal dan eksternal. Secara internal, dosen sebagai figur yang dapat dijadikan teladan. Dosen memberikan teladan dalam berbagai hal yang baik; seperti mengawali dan mengakhiri perkuliahan dengan berdoa, berutur kata dan berperilaku yang sopan, memiliki tanggungjawab, jujur, disiplin dalam memberi kuliah, adil, dan ikhlas dalam mengerjakan segala sesuatu. Sedangkan secara eksternal dapat dilakukan dengan memberikan contohcontoh yang baik dari para tokoh yang dapat diteladani.

Pendekatan klarifikasi nilai digunakan dalam pemantapan nilai-nilai moral melalui proses pengkajian, pemilihan, dan penerapan nilai yang dihadapinya. Pendekatan ini digunakan oleh dosen melalui penerapan strategi 


\section{Drs. Waslah, M.Pd.I}

analisis masalah atau kasus dan penanaman nilai edukatif yang kontekstual. Melalui analisis kasus atau masalah kontekstual yang mengandung nilai-nilai edukatif mahasiswa dapat mendapatkan nilai positif dan negatif dari sebuah kasus. Setelah permasalahan selesai mahasiswa dapat mengambil hikmah atau nilai positif dan dapat belajar dari masalah yang dipecahkan tersebut. Selain itu, mahasiswa juga dapat menerapkan dalam kehidupan mereka terhadap nilai yang baik dari hasil analisis kasus yang telah diselesaikan dalam pembelajaran.

Di samping menggunakan pendekatan yang telah dikemukakan, internalisasi nilai-nilai moral religius dalam proses pembelajaran di perguruan tinggi seharusnya juga dilakukan secara komprehensif. Seperti dikemukakan Howard Kirschenbaum (1995), pendekatan komprehensif dalam pendidikan nilai dapat dijadikan sebagai pilihan. ${ }^{9}$ Isi pendidikan nilai yang akan ditanamkan kepada mahasiswa harus komprehensif. Dalam konteks internalisasi nilai-nilai moral religius dalam proses pembelajaran, maka nilainilai moral religius yang perlu menjadi prioritas utama meliputi nilai ketaqwaan, kejujuran, keikhlasan, dan tanggungjawab. Pemilihan nilai-nilai moral yang menjadi prioritas utama ini sejalan dengan fungsi dan tujuan pendidikan nasional, yaitu mengembangkan potensi peserta didik agar menjadi manusia yang beriman dan bertaqwa kepada Tuhan Yang Maha Esa,

\footnotetext{
${ }^{9}$ Krischenbaum, Howard. 100 Ways to enhance values and morality in schools and
} yauthsettings.(Massachusrts : Allin \&Bacon, 1995 )16-17 


\section{Metode Internalisasi Nilai-Nilai Moral Agama Islam Dalam Proses Pembelajaran}

Di Universitas KH.A.Wahab Hasbullah Tambakberas Jombang

berakhlak mulia, sehat, berilmu, cakap, kreatif, mandiri, dan menjadi warga negara yang demokratis serta bertanggungjawab.

Nilai-nilai moral religius yang lain dapat ditanamkan di luar proses pembelajaran. Misalnya, melalui penciptaan sistem atau suasana kampus yang memungkinkan nilai-nilai moral religius dapat tertanamkan kepada mahasiswa dengan baik. Melalui slogan-slogan yang ada di setiap sudut kampus dapat dijadikan sebagai sarana untuk menanamkan nilai moral religius. Penciptaan program atau kegiatan kampus yang bernuansa religius dapat juga dikembangkan sebagai sarana yang dapat digunakan untuk menginternalisasikan nilai-nilai moral religius dalam kehidupan kampus. Penanaman nilai moral religius hendaknya tidak dilakukan secara parsial tetapi harus mencakup semua nilai-nilai moral religius.

Dari segi metode yang digunakan, internalisasi nilai-nilai moral religius dalam pembelajaran juga harus dilakukan secara komprehensif. Para dosen harus dapat menjadi teladan bagi para mahasiswanya dalam bertindak dan bertutur kata. Mahasiswa perlu disiapkan agar menjadi generasi muda yang mandiri dengan mengajarkan dan memfasilitasi mereka dalam pembuatan keputusan moral secara bertanggungjawab. Selain itu, perlu membekali para mahasiwa dengan keterampilan-keterampilan akademik dan sosial. Mahasiwa dibekali keterampilan berpikir kritis dan keterampilan mengatasi konflik. 


\section{Drs. Waslah, M.Pd.I}

Internalisasi nilai-nilai moral religius perlu dilakukan dalam keseluruhan proses pendidikan di kelas, dalam kegiatan ekstra dan intra kampus, dalam proses bimbingan dengan penasihat akademik, dan dalam semua aspek kehidupan. Mahasiwa dapat melakukan hal ini melalui kegiatan diskusi kelompok, penggunaan bahan-bahan bacaan dan topik-topik tulisan mengenai kebaikan, penggunaan strategi dan klarifikasi nilai dan dilema moral, tidak merokok, tidak berperilaku korup, dermawan, tidak berbohong, dan sebagainya. Internalisasi nilai-nilai moral religius dapat dilakukan oleh setiap dosen, baik terencana ataupun tidak terencana. Kemudian yang terakhir, internalisasi nilai-nilai moral religius dalam proses pembelajaran harus komprehensif dalam segi penilaian. Efektivitas dan kemajuan dari kegiatan ini harus diukur secara komprehensif dengan menggunakan evaluasi formatif dan sumatif yang dapat mengukur pengetahuan, sikap, dan keterampilan yang dimiliki oleh mahasiswa.

\section{E. Catatan Akhir}

Dari penelitian yang telah dilakukan, dapat disimpulkan bahwa strategi implementasi nilai-nilai moral religius yang diterapkan dalam proses pembelajaran Teknik Informasi dan Manajemen, Universitas Universitas KH. Wahab Hasbulloh Tambakberas Jombang meliputi: keteladanan (modelling), analisis masalah atau kasus, penanaman nilai edukatif yang kontekstual, 


\section{Metode Internalisasi Nilai-Nilai Moral Agama Islam Dalam Proses Pembelajaran}

Di Universitas KH.A.Wahab Hasbullah Tambakberas Jombang

penguatan nilai moral yang sudah ada. Nilai-nilai moral religius yang menjadi prioritas utama untuk dikembangkan dalam proses pembelajaran meliputi nilai moral ketaqwaan, kejujuran, keikhlasan, dan tanggungjawab. Masing-masing strategi yang digunakan dalam penanaman nilai moral religius tersebut memiliki kekurangan dan kelebihan masing-masing. Internalisasi nilai-nilai moral religius dalam proses pembelajaran di Universitas KH.A.Waqhab hasbullah Tambakberas jombang dapat menerapkan pendekatan komprehensif yang meliputi aspek isi, metode, waktu, pelaku, dan penilaian.

\section{Ucapan Terima Kasih Kepada:}

1. Lembaga Penelitian (LP2M) Universitas Kh. A. Wahab Hasbullah Tambakberas Jombang

2. Dekan Fakultas Teknik Informasi dan Manajemen, Universitas Universitas KH. Wahab Hasbulloh Tambakberas Jombang yang telah memberikan kesempatan dan ijin untuk melaksanakan penelitian.

3. Bapak/Ibu dosen pengampu mata kuliah di Fakultas Teknik Informasi dan Manajemen

4. Para Mahasiswa Prodi Teknik Informasi dan Ekonomi, Fakultas TI dan Manajemen UNWAHA Tambakberas Jombang. 


\section{Drs. Waslah, M.Pd.I}

\section{DAFTAR PUSTAKA}

Agustian, Ary G. 2008. Peran ESQ dalam Peningkatan Kualitas Pendidikan. Pidato dies natalis ke-44 Universitas Negeri Yogyakarta, 21 Mei 2008. Yogyakarta: UNY Press.

Arikunto, Suharsimi. 2006. Prosedur penelitian: suatu pendekatan praktek. Jakarta: Rineka Cipta.

Bertens, K. 2007. Etika. Jakarta: Gramedia Pustaka Utama.

Cholisin. 1989. Dasar dan konsep pendidikan pancasila. Yogyakarta: Laboratorium Jurusan PMP dan KN.

Kirschenbaum, Howard. 1995. 100 ways to enhance values and morality in schools and youth settings. Massachusetts: Allyn \& Bacon.

Koyan, I Wayan. 2000. Pendidikan Moral Lintas Budaya. Jakarta: Dirjen Dikti, Depdiknas.

Nazir, Moh. 2005. Metode Penelitian. Bogor: Ghalia Indonesia.

PJJ. Jakarta: Dirjen Dikti, Depdiknas R.I.

Republik Indonesia. 2005. Undang-undang nomor 20 tahun 2003 tentang sistem pendidikan nasional.Bandung: Fokusmedia.

Ruminiati. 2007. Modul Pendidikan Kewarganegaraan SD: Untuk Program S1

Wahab, Aziz. 2007. Pendidikan Pancasila dan Kewarganegaraan (PPKn). Jakarta: Penerbit Universitas Terbuka.

Zuchdi, Darmiyati. 2008. Humanisasi Pendidikan: Menemukan Kembali Pendidikan yang Manusiawi. Jakarta: Bumi Aksara. 